\title{
The scientific background of competitive maize production
}

\author{
JÁNOS NAGY - ADRIENN SZÉLES \\ University of Debrecen, Faculty of Agricultural and Food Sciences and \\ Environmental Management, Institute for Land Utilisation, Regional \\ Development and Technology, Debrecen, Hungary \\ nagyjanos@agr.unideb.hu
}

\begin{abstract}
Summary
The effect and interaction of crop production factors on maize yield has been examined for nearly 40 years at the Látókép Experiment Site of the University of Debrecen in a long-term field experiment that is unique and acknowledged in Europe. The research aim is to evaluate the effect of fertilisation, tillage, genotype, sowing, plant density, crop protection and irrigation. The analysis of the database of the examined period makes it possible to evaluate maize yield, as well as the effect of crop production factors and crop year, as well as the interaction between these factors.

Based on the different tillage methods, it can be concluded that autumn ploughing provides the highest yield, but its effect significantly differed in irrigated and non-irrigated treatments. The periodical application of strip tillage is justified in areas with favourable soil conditions and free from compated layers (e.g. strip - strip - ploughing - loosening). Under conditions prone to drought, but especially in several consecutive years, a plant density of 70-80 thousand crops per hectare should be used in the case of favourable precipitation supply, but 60 thousand crops per hectare should not be exceeded in dry crop years. The yield increasing effect of fertilisation is significant both under non-irrigated and irrigated conditions, but it is much more moderate in the non-irrigated treatment.

Selecting the optimum sowing date is of key importance from the aspect of maize yield, especially in dry crop years. Irrigation is not enough in itself without intensive nutrient management, since it may lead to yield decrease.

The results of research, development and innovation, which are based on the performed long-term field experiment, contribute to the production technological methods which provide an opportunity to use sowing seeds, fertilisers and pesticides in a regionally tailored and differentiated way, adapted to the specific needs of the given plot, as well as to plan each operation and to implement precision maize production.
\end{abstract}

Keywords: maize, tillage, fertilisation, plant density, irrigation

\section{Introduction}

Climate change - temperature rises, changes in precipitation, as well as the frequency and intensity of weather extremities - increases the pressure on agrictulture (Net1). This situation is further increased by the 
dynamic population growth. According to forecasts, the global population is expected to exceed nine billion people by 2050. In addition, the increasing living standards result in the increasing extra consumption per person (Net2). Increasing production $(30 \%)$ is important and indispensable from the aspect of feeding the global population. For this reason, great emphasis has to be laid on professional production technology, which, in addition to economic processes, determine the success of crop production, including maize production.

It is the indispensable condition of reaching this objective to obtain thorough knowledge of the composition and characteristics of the production site, to make a conscious choice of hybrids and to apply precision crop production technology.

From year to year, weather causes significant differences between average yields even in the case of modern production technologies. Of the various agroecological factors, the impact of climate is around $63 \%$ in Hungary (Ángyán, 1987). However, on soils with proper water management, risk caused by weather can be significantly reduced (Debreczeni, 1969; Várallyay et al., 1980; Győrffy, 1988).

The examination of the tillage methods of maize ranges from the conventional, high energy need procedures to soil-preserving methods and direct sowing. There were several classic methods of tillage which are currently neglected, such as the timely application of stubble cleaning, the management of the stubble after cleaning and even the autumn primary tillage (Győrffy and Szabó, 1979; Rátonyi et al., 2003, 2005; Nagy, 2007; Birkás, 2010). The proper choice of tillage method with the consideration of maize production level significantly reduces risk (Nagy et al., 2018). KITE Plc. played a pioneering role in applying precision tillage in Hungary by adapting the strip tillage technology originally developed by the American company Orthman (Jóri, 2016).

Harmonious nutrient supply is the indispensable basis of high and safe yield. The efficiency of fertilisers is greatly affected by the climate of the given production site and the weather of the given year (Várallyay and Németh, 1996; Kádár, 2000; Németh, 2001). It is necessary to provide the technical and technological conditions of the application of fertilisers needed for the individual management of the different parts of a plot with different characteristics (Láng and Csete, 1992). The different part of a given plot can be detected with a GPS system and subsequently identified; therefore, following the analysis of soil samples taken from these parts, the use of the obtained results can contribute to determine nutrient supply level and the necessary amount of fertilisers. Based on the used maps, it is possible to work out the individual management of plot parts with different characteristics (Németh, 2001). 
When making a decision about the sowing date of maize, one needs to consider climate, soil quality, geographical location, termperature, weed infestation, as well as sowing seed quality and the ripening time of the hybrid to be produced. Decisions made in the sowing period are very significant, as up to $30 \%$ of the obtained yield may depend on making the proper choice. Deviation from the optimum date (either early or late sowing) may result in yield decrease (Berzsenyi and Dang, 2001; Sárvári and Futó, 2001; Ványiné Széles et al., 2010; Soledad et al., 2013).

Obtaining the satisfactory crop density determines the success of production. Based on the outcome of the first crop density experiments (in 1953), crop density per hectare increased significantly, with the recommended values being 8, 12, 16 and 24 thousand crops per hectare (Berzsenyi-Janosits, 1953; I'só, 1958). In the 1950's, the optimum crop density of maize was 35-40 thousand crops per hectare, which increased to 50 thousand crops by the 1960's and to 55-60 thousands crops by the 1970's (Győrffy, 1976, 1979). Site-specific sowing was one of the most important point of precision farming, since it could lead to even 5-8\% saving of sowing seed. In the case of crop density regulated sowing, the locations of the given plot with different productivity characteristics are taken into consideration; therefore, the crop density of maize can be increased by a few thousand crops on better parts of the plot. By using precision sowing, it is possible to sow several hybrids and different hybrid seeds are sown on different soil patches of the soil in one operation (Neményi, 2013; Milics and Pörneczi, 2015). In order to set the most appropriate date for harvesting, one has to consider the physiological maturity of the produced maize genotype, as well as its rate of water loss based on actual meteorological parameters (Bodnár et al., 2018).

Production technological operations have a significant role in the protection of maize. The properly selected cropping sequence may significantly reduce the damage done by soil-borne pests. Harmonious nutrient replenishment which fits the crop's needs may increase the tolerance of crops againsts pathogens and pests, as it reduces the damage of frit flies, European corn borer and aphids (Bognár et al., 2003; Király, 2005). The stem strength of maize can be increased by applying the proper dose of phosphorus and potassium as per the crop's needs. This proper applications results in the increased tolerance of maize to stem diseases, e.g. fusarium. In addition, optimum crop density is an important crop protection factor due to its role in the microclimatic regulation of the crop stand. High crop density results in higher microclimatic temperature and humidity, which may increase the infestation of European corn borer and aphids, as well as elm-grass root aphid (Glits et al., 1997). The population of leaf aphids and young owlet 
moth caterpillars is especially reduced by the water applied with sprinkler irrigation. However, it has a favourable effect on the development of the corn rootworm and the spreading of pathogens. The application of the environmentally friendly active ingredient indoxacarb with irrigation technology (especially in the case of sweet maize) also serves as protection against the European corn borer and the cotton bollworm (Glits et al., 1997; Balogh et al., 2004; Balogh and Nádasy, 2005).

Based on the obtained agrometeorological data, there was enough precipitation in the Hungarian Great Plain only in $25 \%$ of the examined years; therefore, in order to avoid yield fluctuations depending on different crop years, irrigation to reduce water shortage is indispensable. It is constantly important to look for economic ways of irrigation farming and the area of irrigation farming can be increased where the return of investment is provided (Cselőtei and Harnos, 1996; Lelkes, 2003; Nagy, 2007).

Several Hungarian and international scientific research projects were conducted to analyse the crop production effect of each factor. Of these, the current paper focuses on our main research findings, using the example of maize.

\section{Material and methods}

The examinations were performed in a multifactoral experiment established on the Látókép Experiment Site of the University of Debrecen on mid-heavy calcareous chernozem soil.

The multifactoral long-term experiment has a split-split-plot design, with the main plots representing tillage treatments (autumn ploughing, spring ploughing and spring shallow tillage) and irrigation treatments (non-irrigated and irrigated). The primary subpluts represent the various maize hybrids with crop density values of 50-60-70-80-90 thousand crops, while the secondary subplots represent fertiliser treatments (control, $120 \mathrm{~N}+90 \mathrm{P}_{2} \mathrm{O}_{5}+106 \mathrm{~K}_{2} \mathrm{O} \mathrm{kg} \mathrm{ha}{ }^{-1}$ and $240 \mathrm{~N}+180 \mathrm{P}_{2} \mathrm{O}_{5}+212 \mathrm{~K}_{2} \mathrm{O} \mathrm{kg}$ $\mathrm{ha}^{-1}$ ) in a randomised way with four replications. Plot size was $30 \mathrm{~m}^{2}$.

The average $\mathrm{pH}_{\mathrm{KCl}}$ of the soil was 6.6 (slightly acidic) which is optimal from the aspect of the crops' nutrient uptake. The Arany's plasticity index was 39 in the upper $(20 \mathrm{~cm})$ layer of the soil, while the total amount of water-soluble salts (anions and cations) was $0.04 \%$, which shows low salt content. The carbonic chalk content of the upper $80 \mathrm{~cm}$ layer of the soil is around $0 \%$ (i.e. chalk-deficient), but it is $12 \%$ (moderately chalky) from $100 \mathrm{~cm}$ downwards. The organic matter content is $2.3 \%$ in the upper $20 \mathrm{~cm}$ of the soil, while it does not exceed $1.00 \%$ at the $120 \mathrm{~cm}$ depth. The potassium supply of the soil is satisfactory and its $\mathrm{P}$ supply is average. 
An automatic weather station installed at the Research Station of the University of Debrecen is constantly measuring and logging the environmental parameters. Air temperature $\left({ }^{\circ} \mathrm{C}\right)$ at $0.5 \mathrm{~m}, 1 \mathrm{~m}$ and $2 \mathrm{~m}$ height, relative humidity $(\%)$, soil temperature $\left({ }^{\circ} \mathrm{C}\right)$ at $5 \mathrm{~cm}, 25 \mathrm{~cm}$ and 50 $\mathrm{cm}$ depth, as well as incoming radiation $\left(\mathrm{W} \mathrm{m}^{-2}\right)$ and the amount of precipitation $(\mathrm{mm})$ are measured every 6 seconds.

A general linear model (GLM) was used to detect the effect of treatments on yield (Huzsvai, 2001). During the calculation, the square sums were determined using the Yates' method. To compare the mean values of the various treatments, the significant difference at the $5 \%$ level (LSD $5 \%$ ) was determined and homogeneous groups were formed using Duncan's method, a multiple mean value comparison test. During the multiple comparison, confidence intervals were determined using Bonferroni's method in order to avoid the accumulation of alpha error. Yields within the homogeneous group do not differ from each other at the significance level of 5\%. Evaluation was performed with SPSS for Windows 21.0.

\section{Results}

Field experiments have been undergoing at the Látókép Experiment Site of the University of Debrecen for more than three decades. Based on the data series of these long-term experiments, the weather differences caused by the different crop years greatly affect yield. There is an average quantitative correlation between the two variables, since, in addition to the total amount of precipitation, its temporal distribution is also a significant yield affecting factor. In dry years, the average yield was 6.956 $\mathrm{t} \mathrm{ha}^{-1}$, while water supply resulting from precipitation significantly increased maize yield (by $2.142 \mathrm{t} \mathrm{ha}^{-1}$ ). In dry years, the average yield of maize was $5.183 \mathrm{t} \mathrm{ha}^{-1}$ without fertilisation, while it was $6.785 \mathrm{tha}^{-1}$ in wet years (Figure 1-2).

The lowest average yield of maize was observed in the dry year of $2007\left(4.896 \mathrm{t} \mathrm{ha}^{-1}\right)$ and the highest yield $\left(11.130 \mathrm{t} \mathrm{ha}^{-1}\right)$ was harvested in the wet year of 2016 (Figure 3-4).

The effect of fertiliser treatments on yield is different due to the variability of climatic factors. Under circumstances prone drought, but especially in several consecutive dry years, it is recommended to apply lower fertiliser doses of a maximum of $60 \mathrm{~kg} \mathrm{~N}$ per hectare. By applying any higher fertiliser dose (1995), the producer increases the risk of maize production and reduces the success of production. In the case of favourable water supply, $120 \mathrm{~kg} \mathrm{~N} \mathrm{ha}^{-1}$ is recommended to be applied.

As a part of this research work, we examined the alternatives of minimum tillage with the aim to reduce compaction and production costs. 
The most favourable conditions for maize were provided by autumn ploughing. Yield per hectare was one ton $(12 \%)$ higher than in the case of the spring tillage. The effect of primary tillage on yield was different in each crop year and it greatly depended on water supply. The yield surplus resulting from autumn ploughing - without fertilisation - was 1.4-2.3 $\mathrm{t} \mathrm{ha-1}$ in comparison with spring shallow tillage, while this value was $2.8-3.3 \mathrm{t} \mathrm{ha}^{-1}$ in fertilised treatments.

Figure 1. The natural nutrient conversion ability of maize in dry years (Debrecen, 1999-2016)

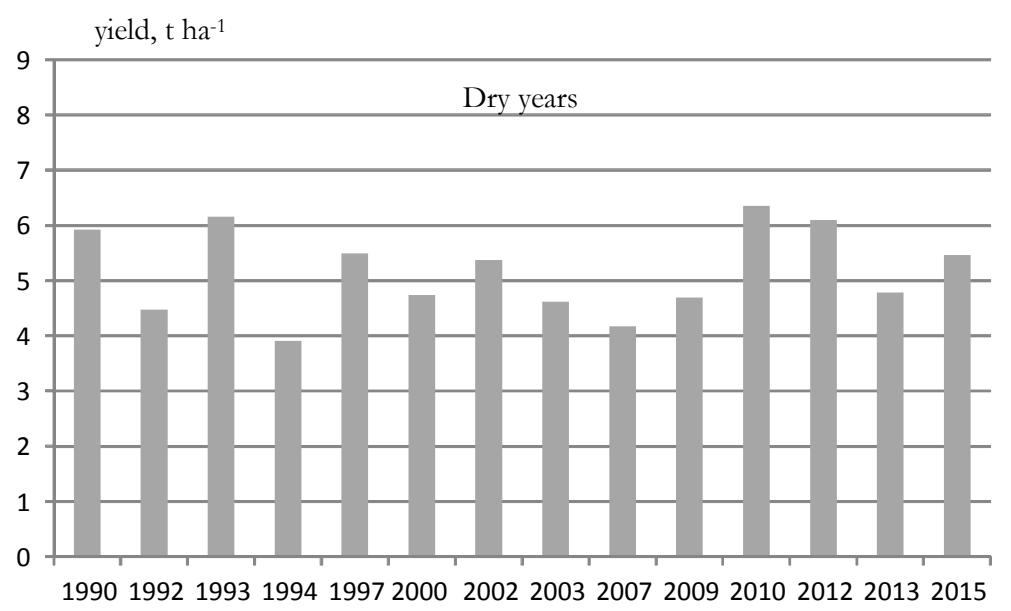

Figure 2. Natural nutrient conversion ability of maize in wet crop years (Debrecen, 1999-2016)

yield, $\mathrm{t} \mathrm{ha}^{-1}$

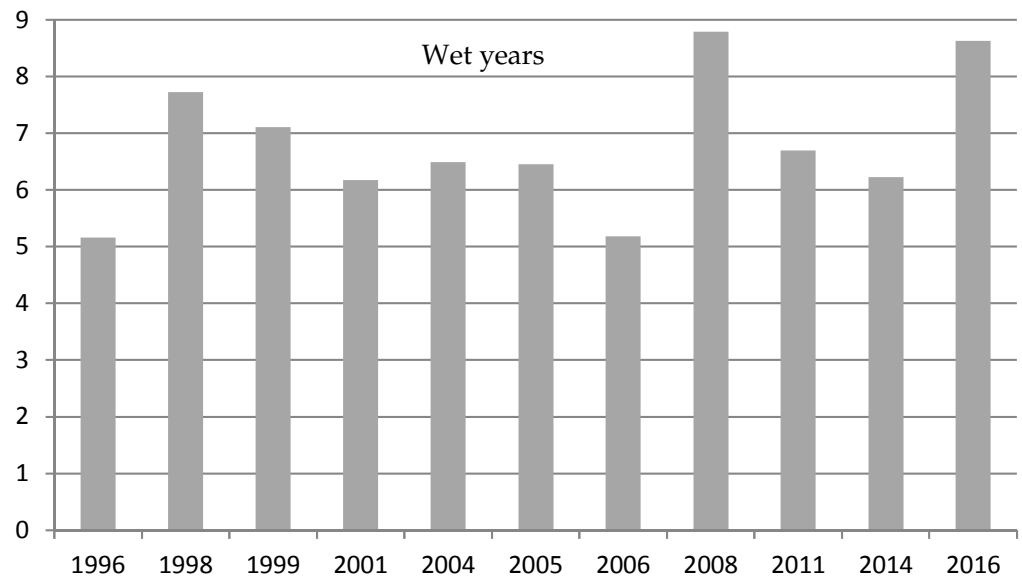


Figure 3. Average yield of maize in dry years

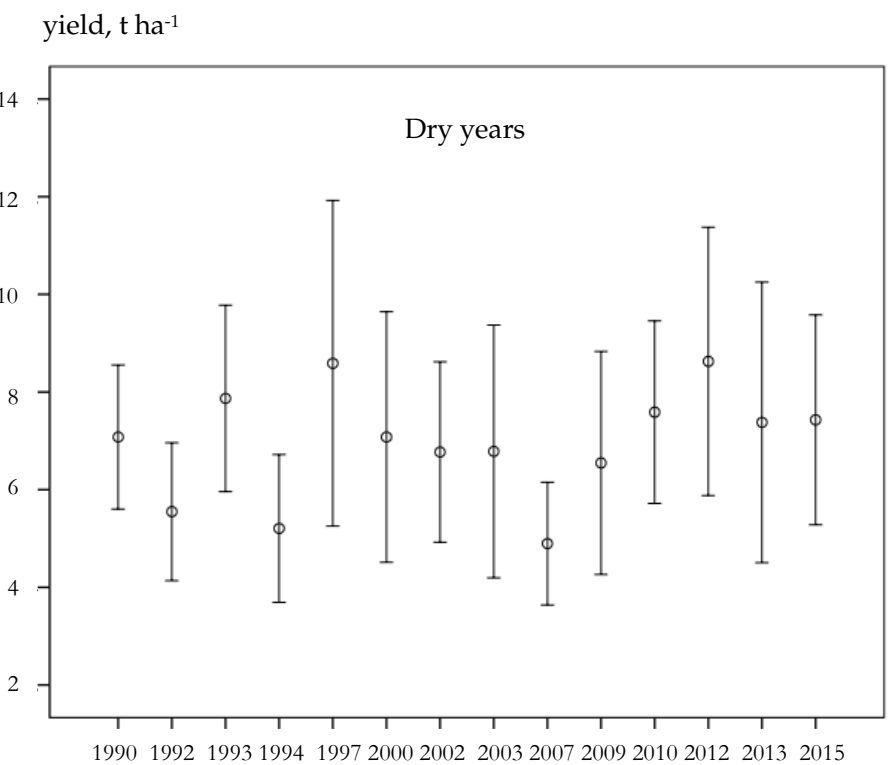

Figure 4. Average yield of maize in wet years yield, $\mathrm{t} \mathrm{ha}^{-1}$

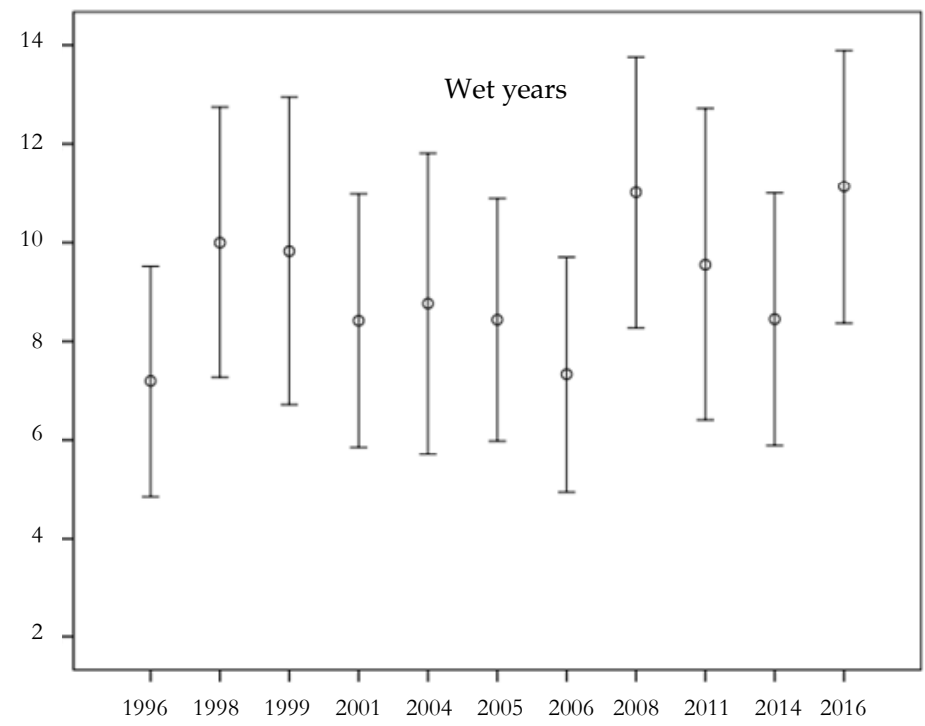


Depending on natural water supply, the effect of irrigation is greatly differentiated in the case of the various tillage methods. The effect of irrigation is the most prominent in autumn ploughing, amounting to 2.87 $t$ ha ${ }^{-1}$ averaged over the examined years. Spring shallow tillage cannot be recommended in irrigation farming on chernozem soil. The effect of irrigation is significant also in spring ploughing, but it has a high risk; therefore, it can only be recommended with great care in practice.

In order to work out precision tillage, the effect of strip tillage on the soil structure and soil compaction was examined in field trials. The obtained findings showed that higher area performance and lower diesel consumption can be achieved on mid-heavy and heavy soils with strip tillage tools in comparison with the ploughing and loosening primary tillage methods (Sulyok et al., 2011; KITE Zrt., 2012, Ferencsik et al., 2014).

In drought years, the sowing date considered to be optimum (third decade of April) was shown to be the best $\left(6.715 \mathrm{t} \mathrm{ha}^{-1}\right)$ from the aspect of yield. In crop years with favourable water supply, early sowing provided the higher yield $\left(9.074 \mathrm{t} \mathrm{ha}^{-1}\right)$, but there was no significant difference between the obtained yield results of different sowing dates (Figure 5).

Figure 5. The effect of sowing date on maize yield

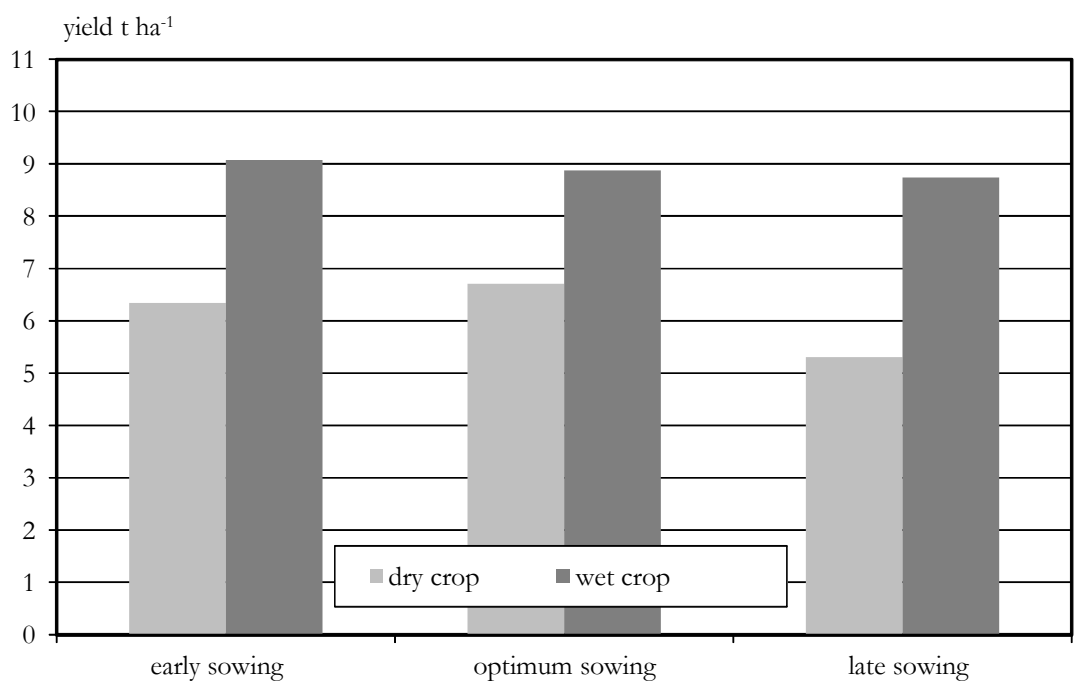

Based on the performed evaluation and considering the results of the examined years, the best crop density value was shown to be 70 thousand crops per hectare. Crop density was not higher than 60 thousand crops per hectaure withough fertilisation or with a low amount of fertiliser. In 
the case of higher crop densities and no fertilisation, the obtained yield was $2-12 \%$ lower in years with average precipitation supply and $3-14 \%$ lower in drought years. In the case of $120 \mathrm{~kg} \mathrm{~N} \mathrm{ha}^{-1}$, the optimum crop density was 70-80 thousand crops per hectare. However, applying $240 \mathrm{~kg}$ $\mathrm{N}$ per hectare at a crop density value of 90 thousand crops per hectare is very risky; therefore, it is not recommended (Figure 6).

Depending on the level of water supply, the effect of crop density was different in each year. In autumn ploughing, the most favourable crop density value was 60-80 thousand crops per hectare. In drought years and years with lower or average precipitation supply, higher crop density values are recommended. The disadvantage of spring ploughing in drought years was measureable also in the obtained yields. If spring ploughing is unavoidable, the maximum crop density is 70 thousand crops per ha, while in the case of dry years, lower crop density values are recommended also in this soil preparation alternative.

Figure 6. The effect of crop density and fertilisation on maize yield

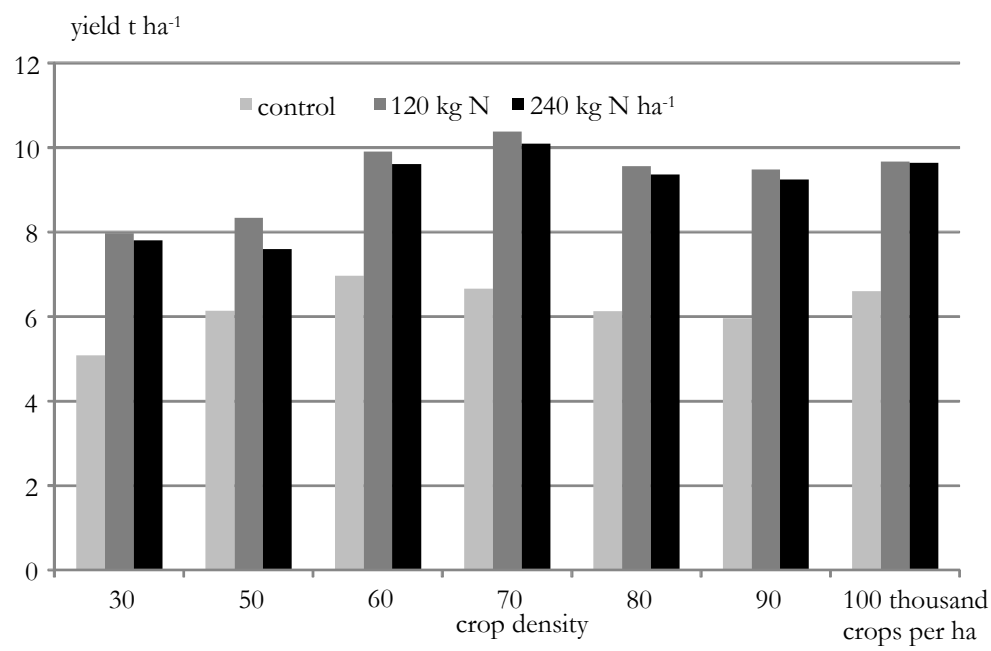

Without irrigation, crop density values higher than 60-70 thousand crops per hectare resulted in $7-14 \%$ yield decrease. In irrigated crop stands, at least 70-80 crops per hectare are needed in order to obtain proper yield. Any higher crop density value is not justified, as our experiments showed a $7-8 \%$ decrease of yield.

In irrigated maize production, nutrient supply level is a key factor. Based on the analysis of various periods, it was concluded that the yield surplus of fertilisation is outstanding, amounting to $4.4 \mathrm{t} \mathrm{ha}^{-1}$ averaged over the examined years. In our experiment, averaged over the examined 
years, the yield surplus of irrigation was $2.6 \mathrm{t} \mathrm{ha}^{-1}$. It was shown that, in drought years, the average yield surplus was $4.5-5 \mathrm{t} \mathrm{ha}^{-1}$, while it was only $0.5-1.5 \mathrm{t} \mathrm{ha}^{-1}$ in years with average precipitation supply.

During the weed control of maize, it represents a problem that dangerous weed species which are difficult to eradicate (Indian mallow, jimsonweed, annual ragweed, millet species, xanthium spinosum species and certain herbicide-resistant biotypes such as amaranth, pigweed and annual ragweed) extremely proliferated in the recent decades. The extent of weed coverage was significantly affected by the previous crop (7.6$8.4 \%$ following wheat; $27.4-35.1 \%$, and $52.3-57.4 \%$ after maize in the weed control treatment). Following a favourable previous crop (wheat), weed coverage was significantly lower than in the case of an unfavourable previous crop (maize). In the case of the same previous crop (maize), the extent of weed infestation was greatly affected by the given crop year and the extent of water supply. In dry years, weed coverage was between $27.4-35.1 \%$ in the weed control treatment, while it was higher in years with favourable water supply (52.3-57.4\%) (Pepó, 2005).

The effect of herbicide treatments on yield depended on the given crop year and previous crop, as well as their effect on weed infestation. In the year with moderate weed coverage, the yield increasing effect of herbicide treatments was $0-500 \mathrm{~kg} \mathrm{ha}^{-1}$ in comparison with the weedy controlm, while it was between $700-2700 \mathrm{~kg} \mathrm{ha}^{-1}$ in the year with average weed coverage and between $3200-4200 \mathrm{~kg} \mathrm{ha}^{-1}$ in the year with strong weed coverage, depending on the applied herbicide and hybrid (Pepó, 2005).

\section{Conclusions}

According to the obtained research findings, the permanent change of climatic factors may significantly affect maize yield. The effects of climate change are either mitigated or intensified by production conditions (tillage, nutrient and water supply level.

After contributing to storing autumn and winter precipitation and the reduction of the number of soil operations in the spring, autumn ploughing provided the highest yield per hectare.

The appearance and acceleration of soil degradation made it necessary to apply new and novel tillage methods, the advantage of which is the significant energy and time saving, in addition to maintaining yield. Also, as a result of strip tillage, the overwhelming majority of stem residues stay on the soil surface, which greatly reduces erosion and the water loss of the soil in dry periods. 
Special attention needs to be drawn to fertilisation, since low nutrient supply deteriorates yield quality. Abundant fertiliser doses (mainly nitrogen) deteriorate quality and reduce potential profit by means of increasing production costs.

Especially in dry years, selecting the optimum sowing date is of chief importance from the aspect of maize yield from the aspect of adapting to changing circumstances.

Crop density greatly affects yield. The obtained findings show that the appropriate crop density value is affected by several factors, such as production site endowments, crop year effect, the quality of tillage, as well as water and nutrient supply. In dry years, lower crop density is recommended, while in wet years or under irrigated conditions, higher crop density is justified.

Currently, irrigation is not only a profit-increasing operation, but it is even more important as a factor which serves market competitiveness. The amount and scheduling of irrigation needs to be set not in accordance with production habitrs, but in consideration of accurate meteorological data and the actual water supply ability the soil, in conformity of the water need of maize adapted to its phenological phases.

Weed control is one of the very important elements of precision production technology. If a crop population is greatly infested with weeds, the favourable effect of fertilisation, crop density and irrigation cannot be properly dominant.

\section{Acknowledgement}

The research serving as a basis of this study was supported by the Excellence Program of Higher Education Institutes announced by the Ministry of Human Resources, within the framework of the Theme 4 Program of the University of Debrecen. The publication was supported by the EFOP-3.6.3-VEKOP-16-2017-00008 project and by the project "Establishing a scale-independent complex precision consultancy system" (GINOP-2.2.1-15-2016-0001). The project is co-financed by the European Union and the European Social Fund.

\section{References}

Ángyán J. (szerk.) (1987): Agroökológiai hatások a kukoricatermesztésben - Az agroökológiai körzetek és a területi fejlesztés. Növénytermesztés korszerúen, gazdaságosan - sorozat. Menyhért Z. (sorozatszerk.), GATE-KSZE, GödöllőSzekszárd. 
Balogh P.-Nádasy M. (2005): Adatok a gyapottok bagolylepke (Helicoverpa armigera Hübner, 1808) biológiájához. XV. Keszthelyi Növényvédelmi Fórum. 8.

Balogh, P.-Takács, J.-Nádasy, M.-Takács, A.-Kutas, J. (2004): The ecologycal study of Helicoverpa armigera Hbn. in Hungary. 56 $6^{\text {th }}$ International Symposium on Crop Protection. Ghent. 153.

Berzsenyi Z.-Lap, D. Q. (2001): A vetésidő és a N-mútrágyázás hatása a kukorica(Zea mays L.) hibridek termésére és termésstabilitására 1991 és 2000 között. Növénytermelés. 50. 2-3: 309-331.

Berzsenyi-Janosits L. (1953): Tenyészterület-kísérlet kukoricával. Növénytermelés. 2: $110-115$.

Birkás M. (szerk.) (2010): Talajmúvelők zsebkönyve. Mezőgazda Kiadó. Budapest. 282.

Bodnár, K. B.-Nagy, J.-Gombos, B. (2018): Correlations between meteorological parameters and the water loss of maize from silking to harvesting. Proceedings of the $14^{\text {th }}$ International conference on Precision Agriculture. 2427 June 2018. Montreal. Quebec. Canada. 1-3.

Bognár S.-Jenser G.-Pénzes B.-Vörös G. (2003): A kártevők elleni védekezés integrált termesztésben. [In: Jenser G. (szerk.) Integrált növényvédelem a kártevők ellen-] Mezőgazdasági Kiadó. Budapest.

Cselőtei L.-Harnos Zs. (1996): Éghajlat, Időjárás, aszály. II. Az aszály enyhítésének lehetőségei. Akadémiai Kiadó. Budapest.

Debreczeni B. (1969): A mútrágyázás, az öntözés és a talajtípus néhány összefüggése a kukoricatermesztésben. [In: I'só I. (szerk.) Kukoricatermesztési kísérletek 1965-1968.] Akadémiai Kiadó. Budapest. 423-432.

Ferencsik S.-Rátonyi T.-Fejér P.-Harsányi E. (2014): A kukorica talajmúvelési rendszereinek összehasonlító elemzése réti csernozjom talajon. Agrártudományi Közlemények. 60: 21-24.

Glits M.-Horváth J.-Kuroli G.-Petróczi I. (szerk.) (1997): Növényvédelem. Mezőgazdasági Kiadó. Budapest.

Győrffy B.-Szabó J. L. (1979): A talajmúvelés optimális mélysége és a no-tillage vizsgálata kukorica monokultúrában. [In: Bajai J. (szerk.) Kukoricatermesztési kísérletek 1968-1974.] Akadémiai Kiadó. Budapest. 186-206.

Győrffy B. (1976): A kukorica termésére ható növénytermesztési tényezők értékelése. Agrártudományi Közlemények. 35: 239-266.

Győrffy B. (1979): Fajta, növényszám- és mútrágyahatás a kukoricatermesztésben. Agrártudományi Közlemények. 38: 309-331.

Győrffy B. (1988): Az 1983. évi aszály hatása és tanulságai. Magyar Tudomány. 4: 249-254.

Huzsvai L. (2001): Tartamkísérletek kiértékelése új szemszögból. Agrártudományi Közlemények. 1: 55-60.

I'só I. (1958): Országos tenyészterület kísérletek eredményei. [In: I'só I. (szerk.) Kukoricatermesztési kísérletek 1953-1957.] Akadémia Kiadó. Budapest. 205222.

Jóri J. I. (2016): Horizontális-vertikális-precíziós alapmúvelés. Agrofórum. 27. 10: 24-32.

Kádár I. (2000): A kukorica tápelem-felvétele és trágyaigénye. Agrofórum. 11. 3: $41-43$. 
Király Z. (2005): A modern kutatás-oktatás nemzetközi jellege. [In: Nagy J.Kovács J. (szerk.) Személyiségek a magyar agráriumban I.] Debreceni Egyetem Agrártudományi Centrum. Debrecen. 115-128.

KITE Zrt. (2012): Új irányok - innovatív technológiák a KITE-tól. AGROmash EXPO 2012. www.kite.hu

Láng I.-Csete L. (1992): A tápanyag-gazdálkodás. [In: Láng I.-Csete L. (szerk.) Az alkalmazkodó mezőgazdaság.] Agricola Kiadói és Kereskedelmi Kft. Budapest. 83-84.

Lelkes J. (2003): Öntözni csak precíziós módszerekkel érdemes. Agrofórum. 14. 7: 6-8.

Milics G.-Pörneczi A. (2015): A kukorica helyspecifikus vetése. Agrofórum. 26. 4: 128-130.

Nagy F.-Nagy O.-Bodnár K. B. (2018): Talajmúvelési módok kockázatelemzése öntözéses gazdálkodásban. Növénytermelés. 67. 1: 5-18.

Nagy J. (2007): Kukoricatermesztés. Akadémiai Kiadó. Budapest.

Neményi, M. (2013): Precision Crop Production and Sustainability. [In: Neményi M. et al. (szerk.) "Science for Sustainability" International Scientific Conference for PhD Students. Nyugat-magyarországi Egyetem Kiadó. Sopron. 211-212.

Németh T. (2001): A tápanyag-gazdálkodás szerepe a szántóföldi növénytermesztésben. [In: Kovács F. et al. (szerk.) Lehetőségek az agrártermelés környezetbarát fejlesztésében.] MTA Agrártudományok Osztálya. Budapest. 106-132.

Net1: https://www.oecd.org/tad/sustainable-agriculture/agriculture-climatechange-september-2015.pdf

Net2: http://www.slate.com/articles/technology/future_tense/2012/04/heat resistant_seeds_ecological_agriculture_growing_food_after_climate_change_. html

Pepó P. (2005): A hibridspecifikus gyomirtás új eredményei a kukoricatermesztésben. [In: Nagy J. (szerk.) Kukoricahibridek adaptációs képessége és termésbiztonsága.] Debreceni Egyetem Agrártudományi Centrum. Debrecen. 165-182.

Rátonyi T.-Megyes A.-Nagy J. (2003): Talajvédő termesztéstechnológiai rendszerek értékelése. [In: Nagy J. (szerk.) Kukorica hibridek adaptációs képességének és termésbiztonságának javítása.] Debreceni Egyetem Agrártudományi Centrum. Debrecen. 141-148.

Rátonyi, T.-Huzsvai, L.-Nagy, J.-Megyes, A. (2005): Evaluation of soil tillage systems in maize production. Acta Agronomica Hungarica. 53. 1: 53-57.

Sárvári M.-Futó Z. (2001): A vetésidő hatása a különböző genetikai adottságú kukoricahibridek termésére. Növénytermelés. 50. 1: 43-60.

Soledad, V. L.-Blanco, M.-Cortada, L.-Sorribas, F. J. (2013): Resistance of tomato rootstocks to Meloidogyne arenaria and Meloidogyne javanica under intermittent elevated soil temperatures above $28^{\circ} \mathrm{C}$. Crop Protection. 46 : $57-$ 62.

Sulyok, D.-Rátonyi, T.-Huzsvai, L.-Ferencsik, S.-Harsányi, E. (2011): Precision farming and economic questions of fertilisation. Növénytermelés. 60: 251-254. 
Ványiné Széles A.-Megyes A.-Nagy J. (2010): A vetésidő és az évjárat hatása a kukorica (Zea mays L.) hibridek terméshozamára és minőségére. Növénytermelés. 59. 4: 63-88.

Várallyay Gy.-Németh T. (1996): A fenntartható mezőgazdaság talajtaniagrokémiai alapjai. MTA Agrártudományok Osztályának tájékoztatója. Akadémiai Kiadó. Budapest. 80-92.

Várallyay Gy.-Szücs L.-Rajkai K.-Zilahy P.-Murányi A. (1980): Magyarországi talajok vízgazdálkodási tulajdonságainak kategóriarendszere és 1:100000 méretarányú térképe. Agrokémia és Talajtan. 29: 77-112. 